\title{
HAK ASASI MANUSIA DAN PERLINDUNGAN LINGKUNGAN HIDUP
}

\author{
Priya Tandirerung Pasapan \\ Universitas Kristen Indonesia Paulus; rantebua@gmail.com
}

\begin{abstract}
Abstrak
Perhatian terhadap masalah lingkungan hidup tidak hanya sebatas masalah lokal atau nasional tetapi juga merupakan masalah internasional. Perlindungan terhadap lingkungan hidup telah menjadi agenda besar komunitas masyarakat internasional yang didasari pada kenyataan berbagai peristiwa pencemaran dan kerusakan lingkungan yang membawa dampak sangat besar dalam kehidupan manusia. Artikel ini menganalisis hubungan antara lingkungan hidup dengan Hak Asasi Manusia dan kebijakan pemerintah Indonesia dalam melakukan perlindungan lingkungan Hidup. Tujuan penulisan ini adalah mengetahui korelasi antara Hak Asasi Manusia dengan lingkungan hidup, dan mengetahui kebijakan pemerintah Indonesia terkait hal tersebut. Melalui artikel ini diketahui bahwa lingkungan hidup merupakan bagian yang inheren dengan Hak Asasi Manusia, di mana hak atas lingkungan hidup yang baik dan sehat merupakan Hak Asasi Manusia. Selain itu, pemerintah Indonesia juga telah mengambil langkah dan upaya dalam menjamin perlindungan lingkungan hidup yang salah satunya melalui instrumen hukum undang-undang.
\end{abstract}

Kata Kunci : Hak Asasi Manusia; Lingkungan Hidup; Perlindungan

\begin{abstract}
Attention to environmental issues is not only limited to local or national problems but also as an international problem. Protection of the environment has become a main agenda of the international community. This program based on the reality of various environmental pollution and damage events that have had a profound impact on human life. This article analyzes the relationship between the environment and human rights and the Indonesian government's policy to protect the environment. The purposes of this paper are to find out the correlation between human rights and the environment, and find out the policies of the Indonesian government in this regard. Through this article, it can be seen that the environment is an inherent part of human rights, which the right to a good and healthy environment is a human right. Furthermore, the Indonesian government has also taken steps and efforts in ensuring environmental protection, one of which is through legal instruments of the law.
\end{abstract}

Keywords : Human Rights; Environment; Protection

\section{Pendahuluan}

"Merawat ekosistem mengandaikan pandangan yang jauh ke depan, karena jika kita hanya mencari keuntungan secara cepat dan mudah, tidak akan ada yang peduli pada pelestarian alam". ${ }^{1}$ Penggalan kalimat tersebut merupakan salah satu penggalan yang terdapat dalam Ensiklik Laudato Si yang dikeluarkan oleh Paus Fransiskus sebagai Pimpinan Tertinggi Tahta Suci Vatikan sebagai bentuk respon atas realitas lingkungan hidup yang terjadi dewasa ini. Dalam konteks ini, kerusakan

\footnotetext{
${ }^{1}$ F.X. Adisusanto, Maria Ratnaningsih, Bernadeta Harini Tri Prasasti (ed), 2016, Laudato Si Terpujilah Engkau, Departemen Dokumentasi dan Penerangan Konferensi Waligereja Indonesia, Jakarta, hal. 25
} 
lingkungan yang terjadi di dunia tidak hanya merupakan suatu permasalahan di tingkat regional atau nasional, melainkan merupakan permasalahan global yang dialami seluruh umat manusia. Hal ini merupakan suatu bentuk keprihatinan, mengingat hak atas lingkungan merupakan akses terhadap sumber daya alam yang utuh dan merupakan salah satu bentuk hak manusia untuk menikmati dan hidup di alam yang lebih baik.

Hak Asasi Manusia (HAM) dan lingkungan hidup memiliki korelasi yang sangat erat dan saling membutuhkan, sehingga setiap upaya penghargaan dan perlindungan terhadap lingkungan hidup juga merupakan bentuk penghargaan terhadap HAM. Perubahan yang terjadi pada lingkungan hidup sangat tergantung dari perbuatan manusia. Keadaan alam yang ada secara fisik dapat digunakan untuk kepentingan manusia dalam mengupayakan kehidupan yang lebih baik dan sehat. Namun, pandangan ini akan menjadi berat sebelah, ketika lingkungan hidup hanya dimaknai sebagai obyek yang digunakan untuk kepentingan manusia semata. Lingkungan hidup merupakan ruang yang ditempati oleh manusia bersama dengan makhluk hidup lainnya, di mana masing-masing tidak dapat berdiri sendiri melainkan saling berinteraksi dan saling membutuhkan satu sama lain. Dapat dikatakan bahwa hubungan dan saling interaksi ini merupakan tatanan ekosistem yang mengandung esensi penting lingkungan hidup sebagai satu kesatuan yang tidak dapat dibicarakan secara persial. Lingkungan hidup harus dipandang secara holistik dan mempunyai sistem yang teratur serta diletakannya semua unsur didalamnnya secara setara ${ }^{2}$

Hubungan yang baik antara manusia dengan lingkungan hidup ditegaskan dalam Mukadimah The Rio Declaration on Environment and Development tahun 1992. Dalam Mukadimah ditegaskan mengenai posisi sentral dari dua hubungan yang aktif antara manusia dengan alam lingkungan hidupnya. ${ }^{3}$ Alam merupakan wahana lingkungan hidup bagi manusia, di mana alam akan dapat bertahan sebagai sumber kehidupan ketika alam dirawat, dijaga, dan dilestarikan, sehingga jika terjadi kerusakan pada alam, maka terjadi pula kerusakan dalam hidup manusia. Kerusakan alam merupakan bukti kebodohan yang paling fundamental karena mewariskan kerusakan serupa pada generasi-generasi selanjutnya. ${ }^{4}$

Perlindungan terhadap lingkungan hidup menjadi bentuk konsekuensi logis atas terjadinya kerusakan ekosistem alam itu sendiri. Hal ini juga merupakan bentuk pencegahan terhadap kerusakan ekosistem alam yang lebih besar lagi. Problematika lingkungan hidup yang merupakan problematika hingga tingkat global membawa

\footnotetext{
${ }^{2}$ M. Ridha Saleh. (2006). Lingkungan Hidup : Untuk Penghidupan Bukan Untuk Pertumbuhan, WALHI, Jakarta, hal. 11-12

${ }^{3}$ Rochmani, (2015), Perlindungan Hak Atas Lingkungan Hidup Yang Baik Dan Sehat di Era Globalisasi, Jurnal Masalah-Masalah Hukum, v44n1, hal. 21

${ }^{4}$ Majda El-Muhtaj, (2008), Dimensi-Dimensi HAM Mengurai Hak Ekonomi, Sosial, dan Budaya, PT Raja Grafindo Persada, Jakarta, hal. 193
} 
konsekuensi pada timbulnya gerakan dunia untuk memberikan perhatian yang lebih besar pada lingkungan hidup. Hal ini mengingat kenyataan bahwa lingkungan hidup telah menjadi bagian yang harus ditanggulangi bersama masyarakat internasional demi kelangsungan hidup di bumi ini. Perhatian terhadap masalah lingkungan hidup ini dimulai di kalangan Dewan Ekonomi dan Sosial Perserikatan Bangsa-Bangsa (PBB) saat diadakan peninjauan terhadap hasil-hasil gerakan "Dasawarsa Pembangunan Dunia ke 1"5.

Sebagai bagian dari hak asasi manusia, maka negara harus menghormati, memenuhi, dan melindungi hak atas lingkungan hidup yang baik dan sehat. Untuk memenuhi hak atas lingkungan hidup yang baik dan sehat tersebut, setiap orang diberikan hak untuk mendapatkan pendidikan lingkungan hidup, akses informasi, akses partisipasi, dan akses keadilan. Perlindungan dan jaminan hak asasi atas lingkungan hidup yang baik dan sehat memerlukan instrumen hukum yang berorientasi pada pemulihan tata hubungan manusia dengan lingkungan hidup. Dalam hal ini, salah satu sarana ampuh dalam rangka melindungi lingkungan hidup adalah hukum, yaitu hukum yang mengatur perlindungan lingkungan hidup (Environmental Protection Law). ${ }^{6}$

\section{Metode}

Penulisan artikel ini menggunakan metode penelitian hukum dengan pendekatan yuridis normatif dengan mengacu pada norma-norma hukum internasional dan hukum nasional. Data yang digunakan dalam artikel ini adalah data sekunder berupa bahan hukum primer yaitu norma hukum internasional yaitu Deklarasi Universal Hak Asasi Manusia, Kovenan Internasional Hak Ekonomi, Sosial dan Budaya, dan berbagai kovenan terkait perlindungan lingungan hidup. Bahan hukum primer lain yang digunakan adalah kebijakan nasional terkait perlindungan lingkungan hidup, yaitu Undang-Undang Nomor 32 Tahun 2009 tentang Pengelolaan Lingkungan Hidup (UUPLH). Selain itu, digunakan juga bahan hukum sekunder yaitu literatur berupa buku, jurnal, dan artikel terkait. Analisis data dalam artikel ini menggunakan analisis kualitatif dengan mendeskripsikan fakta-fakta yang ada, kemudian dilakukan analisis berdasarkan norma hukum yang berlaku maupun teori yang ada.

\section{Hak Atas Lingkungan Hidup}

Globalisasi yang salah satunya ditandai dengan pembangunan di segala bidang membawa konsekuensi logis terhadap keberadaan lingkungan hidup. Aktivitas yang dilakukan oleh perusahaan-perusahaan besar atas nama

\footnotetext{
${ }^{5}$ Koesnadi Hardjasoemantri, dalam Richard V. Waas, (2014), Perlindungan Hukum Terhadap Hak Atas Lingkungan Hidup Ditinjau Dari Perspektif Hukum Internasional dan Hukum Nasional Indonesia, Jurnal Sasi, v20n1, hal. 82

${ }^{6}$ Munadjat Danusaputra. (1985). Hukum Lingkungan, Buku I, Binacipta, Jakarta, hal. 70
} 
pembangunan yang hanya berorientasi pada keuntungan secara terus menrus telah menyerobot keberadaan lingkungan hidup yang berdampak pada kehidupan manusia. Dampak negatif yang ditimbulkan dari berbagai program pembangunan terhadap lingkungan hidup memunculkan kategori atau bentuk lain dari pemenuhan hak, yaitu hak atas lingkungan hidup. Dalam konteks perlindungan HAM, baik hak sipil politik, hak ekonomi, sosial dan budaya, hak atas pembangunan dan hak atas lingkungan merupakan hak yang bersifat universal dan melekat dalam diri manusia, sehingga merupakan kewajiban masyarakat internasional serta negara untuk memberikan jaminan perlindungan atasnya.

Korelasi antara HAM dan lingkungan hidup terlihat dari hak atas lingkingan hidup yang menjadi insrtumen dalam HAM, bahwa salah satu hak yang asasi bagi manusia adalah hak atas lingkungan yang baik dan sehat. ${ }^{7}$ Terdapat dua aspek yang membentuk hak atas lingkungan, yaitu aspek substantif dan aspek prosedural. Aspek substantive merupakan aspek substansial dari hak atas lingkungan hidup, dimana setiap orang berhak atas lingkungan hidup yang baik dan sehat. Sedangkan aspek prosedural merupakan hak atas lingkungan yang bersifat prosedural atau menjadi pilar dalam mewujudkan pemenuhan hak atas lingkungan secara substansial. Hakhak prosedural ini disepakati di Aarhus, Denmark dalam Aarhus Convention 1998. Pilar-pilar yang tergolong hak prosedural tersebut terdiri atas access to information, public participation in decision-making dan access to justice. ${ }^{8}$

Hubungan antara HAM dan lingkungan dalam konteks masyarakat internasional secara resmi pertama kali muncul pada tahun 1972 melalui Konferensi Stockholm tentang Lingkungan Hidup Manusia. Kemudian dilanjutkan dalam Pertemuan Rio de Janeiro (Earth Summit) pada tahun 1992 yang berhasil aturan normatif untuk hak-hak manusia dan lingkungan yang diatur dalam Deklarasi Rio dan Rencana Aksi Agenda 21. Selanjutnya pada tahun 1994, Reportur Khusus PBB untuk Hak Asasi Manusia dan Lingkungan untuk Sub Komisi Pencegahan Diskriminasi dan Perlindungan Kaum Minoritas mengeluarkan analisis yang mengenai hubungan antara HAM dan lingkungan. Laporan ini menyimpulkan bahwa kerusakan lingkungan telah menyebabkan dampak serius terhadap kualitas hak-hak asasi manusia. ${ }^{9}$

Perlindungan hukum terhadap hak masyarakat untuk memperoleh lingkungan hidup yang baik dan sehat telah diamanatkan dalam berbagai instrumen hukum, baik di tingkat lokal, nasional, maupun internasional. Dalam African Charter on Human and Peoples Rights pada Pasal 21 ayat (4) menyatakan bahwa "semua rakyat dapat secara bebas mengatur segala kekayaan dan sumber daya mereka. Hak ini dilaksanakan atas kepentingan eksklusif bangsa. Tidak dibenarkan suatu bangsa merampas upaya penghidupannya sendiri". Kovenan Internasional Hak Ekonomi,

\footnotetext{
7 Abdurrahman Supardi Usman. (2018). Lingkungan Hidup Sebagai Subjek Hukum : Redefinisi Relasi Hak Asasi Manusia dan Hak Asasi Lingkungan Hidup Dalam Perspektif Negara Hukum, Jurnal Legality, v26n1, hal. 10 8 Ibid

${ }^{9}$ Longgena Ginting, dalam M. Ridha Saleh, Op.cit, hal. 7
} 
Sosial dan Budaya juga memberikan pengaturan mengenai hak atas lingkungan sebagaimana yang tertuang dalam Pasal 1 ayat (2) bahwa 'semua rakyat dapat secara bebas mengatur segala kekayaan dan sumber daya mereka sendiri, tanpa mengurangi kewajiban-kewajiban yang mungkin timbul dari kerjasama ekonomi internasional atas dasar prinsip keuntungan bersama serta hukum internasional. Tidak dibenarkan suatu bangsa merampas upaya penghidupan rakyatnya sendiri".

Resolusi PBB 1803 (XVII) pada 14 Desember 1962 pada pokoknya menyatakan bahwa adalah hak rakyat untuk dengan bebas mengatur kekayaan dan sumber daya alam mereka. Begitupun pada Resolusi PBB 3281 (XXIX) 12 Desember 1974, yang mana salah satu tujuannya adalah guna menciptakan kondisi perlindungan, pelestarian dan peningkatan kualitas lingkungan hidup. Hak atas lingkungan sebagai HAM barulah mendapatkan pengakuan dalam bentuk kesimpulan oleh Sidang Komisi Tinggi HAM pada bulan April 2001, yang menyatakan bahwa setiap orang memiliki hak hidup di dunia yang bebas dari polusi bahan-bahan beracun dan degradasi lingkungan hidup. ${ }^{10}$

Pada tataran nasional, Konstitusi Republik Indonesia juga memberikan perhatian pada hak atas lingkungan. Dalam Pasal $28 \mathrm{H}$ ayat (1) menyebutkan bahwa setiap orang berhak sejahtera lahir dan batin, bertempat tinggal dan mendapatkan lingkungan hidup yang baik dan sehat serta berhak memperoleh pelayanan kesehatan. Ketentuan tersebut memuat jaminan bahwa hak atas lingkungan hidup sudah menjadi kewajiban hukum bagi negara untuk menjaga dan menjunjung tinggi hak rakyat tersebut. Dengan demikian, terdapat jaminan hak hidup layak dan bersih yang menjadi esensi hak hidup masyarakat. Sebagai turunan atas Undang-Undang Dasar Negara Republik Indonesia Tahun 1945, jaminan perlindungan hak atas lingkungan hidup juga diatur dalam Undang-Undang Nomor 32 Tahun 2009 tentang Perlindungan dan Pengelolaan Lingkungan Hidup. Dalam Pasal 65 ayat (1) disebutkan bahwa setiap orang berhak atas lingkungan yang baik dan sehat sebagai bagian dari hak asasi manusia. Untuk memenuhi hak tersebut, setiap orang berhak mendapatkan pendidikan lingkungan hidup, akses informasi, akses partisipasi dan akses keadilan, sebagaimana yang dinyatakan dalam ayat (2).

Mengenai beberapa pengaturan mengenai hak atas lingkungan hidup baik di tingkat nasional maupun internasional, Paul Sieghart mengungkapkan bahwa hak aas lingkungan merupakan hak yang tidak dapat dikurangi dalam kondisi apapun, di samping itu juga tidak diperbolehkan adanya diskriminasi apapun dalam penghormatan hak atas lingkungan. ${ }^{11}$ Sebagai hak yang melekat dalam diri manusia, maka terdapat kewajiban hukum yaitu :

a. to take steps (mengambil langkah);

b. to guarantee (menjamin);

\footnotetext{
${ }^{10}$ M. Ridha Saleh, Op.cit, hal. 13

11 Ibid, hal. 14
} 
c. to ensure (meyakini);

d. to recognize (mengakui);

e. to respect or to respect for (menghormati atau memberikan penghormatan);

f. to undertake (berusaha);

g. to promote (meningkatkan). ${ }^{12}$

Sekian kewajiban hukum tersebut dapat dijadikan sebagai acuan bagi negara-negara dalam proses perlindungan dan pemenuhan hak asasi yang terkait dengan lingkunga hidup.

\section{Perlindungan Lingkungan Hidup Sebagai Perlindungan HAM}

Sebagaimana telah disebutkan bahwa terdapat korelasi antara kehidupan manusia dengan keberadaan lingkungan hidup. Perlindungan terhadap hak atas lingkungan hidup seringkali dimaknai keliru oleh beberapa pihak yang dalam hal ini hanya menggunakan haknya untuk memanfaatkan lingkungan, namun tidak memperhitungkan perlindungan terhadap lingkungan hidup itu sendiri dan dampaknya bagi kehidupan manusia yang lain. Dalam hal ini masih terdapat dikotomi antara hak atas lingkungan hidup dengan hak asasi manusia. Padahal, pada dasarnya kedua hak tersebut merupakan satu kesatuan yang tidak dapat mengeliminasi salah satunya. Dengan demikian, permasalahan lingkungan hidup juga merupakan permasalahan hak asasi manusia karena hanya didasarkan pada hak atas lingkungan hidup atau hak atas pembangunan. Otto Soemarwotto mengatakan bahwa pembangunan dapat dan telah menyebabkan masalah lingkungan yang mengurangi, dan bahkan dapat meniadakan manfaat pembangunan. ${ }^{13}$

Proses pembangunan yang tidak memperhatikan perlindungan terhadap lingkungan hidup menjadi permasalahan yang sangat serius, mengingat kerusakan lingkungan yang ditimbulkan semakin mengkhawatirkan. Atas dasar tersebut, perhatian masyarakat internasional terhadap perlindungan lingkungan hidup sebagai bentuk perwujudan hak asasi manusia semakin mengemuka pada Konferensi Stochkholm tahun 1972 yang merupakan konferensi pertama yang membahas mengenai permasalahan lingkungan hidup. Konferensi ini mengangkat tema pembangunan berkelanjutan sebagai bentuk antitesa atas proses pembangunan yang menyebabkan kerusakan lingkungan hidup. Sebagai tindak lanjut Konferensi ini, pada tahun 1983 dibentuk World Commision on Environment and Development (WCED) berdasarkan keputusan Sidang Umum PBB. Adapun tugas dari lembaga ini adalah a. Mengajukan strategi jangka panjang pengembangan lingkungan menuju pembangunan yang berkelanjutan di tahun 2000 dan sesudahnya;

\footnotetext{
${ }^{12}$ Richard V. Waas, Op.cit, hal. 84

${ }^{13}$ Otto Soemarwotto. (1997). Ekologi Lingkungan dan Pembangunan, Djambatan, Jakarta, hal. 9
} 
b. Mengajukan cara-cara supaya keprihatinan lingkungan dapat dituangkan dalam kerja sama antaranegara untuk mencapai keserasian antara kependudukan, sumber daya alam, lingkungan dan pembangunan;

c. Mengajukan cara-cara supaya masyarakat internasional dapat menanggapi secara lebih efektif pola pengembangan berwawasan lingkungan; dan

d. Mengajukan cara-cara masalah lingkungan jangka panjang yang dapat ditanggapi dalam agenda aksi untuk dasawarsa pembangunan. ${ }^{14}$

Konsep mengenai pembangunan berkelanjutan semakin popular pada dekade tahun 1980-an dalam strategi Konservasi Dunia yang dikaitkan dengan sumber daya alam beserta implikasinya dalam pengelolaan lingkungan hidup dan hak asasi manusia. Konsep pembangunan berkelanjutan kemudian dikaji secara mendalam pada Konferensi Tingkat Tinggi PBB yang dihadiri oleh 154 negara anggota di Rio de Janeiro, Brazil pada Juni 1992, yang menggariskan prinsip-prinsip fundamental tentang lingkungan dan pembangunan. ${ }^{15}$ Sebanyak 27 prinsip fundamental dihasilkan dalam Konferensi ini yang pada intinya memberikan perlindungan bagi lingkungan hidup. Menurut Koesnadi Hadjasoemantri, Konferensi Rio menemukan dua hasil utama, yaitu Pertama, Konferensi Rio telah mengaitkan dengan sangat tepat dua pengertian kunci, yaitu pembangunan seluruh bumi dan perlindungan lingkungan. Kedua, jalan yang dilalui kini telah diterangi oleh penerang baru yaitu semangat Rio yang meliputi tiga dimensi yaitu dimensi intelektual, dimensi ekonomi dan dimensi politik. ${ }^{16}$ Dimensi intelektual merupakan pengakuan terhadap adanya saling ketergantungan antara satu dengan yang lainnya di bumi ini. Dimensi ekonomi, berupa keprihatinan bersama terhadap kurangnya pembangunan dan pembangunan yang berlebihan, yang selanjutnya harus diganti dengan pembangunan seluruh bumi. Dimensi politik, berupa munculnya kesadaran yang jelas tentang kewajiban politik, berupa kewajiban jangka panjang. ${ }^{17}$

Baik Konferensi Stockholm maupun Konferensi Rio telah memberikan perhatian besar kepada penghormatan dan perlindungan HAM atas lingkungan hidup. Klaus Toepfer, Direktur Eksekutif Program Lingkungan PBB menegaskan bahwa Konferensi Stockholm sangat tepat dijadikan sebagai pendekatan dalam memahami perlindungan lingkungan yang berimplikasi pada pemenuhan HAM. ${ }^{18}$ Dalam Konferensi Rio memberikan kesadaran universal untuk mampu mewariskan bumi yang lestari bagi generasi yang akan datang. Dengan demikian, perlindungan terhadap HAM tidak lagi dianggap sebagai hal yang parsial dengan perlindungan terhadap lingkungan hidup. Hal ini berarti, pemerintahan di seluruh dunia memiliki

\footnotetext{
${ }^{14}$ Richard V. Waas, Op.cit, hal. 85

${ }^{15}$ Gatot P. Soemartono. (1996). Hukum Lingkungan Indonesia, Sinar Grafika, Jakarta, hal. 38

${ }^{16}$ Morais Barakati. (2015). Perspektif Konsep Hukum Hak Asasi Manusia Dalam Mewujudkan Pembangunan Lingkungan Hidup Yang Berkelanjutan, Jurnal Lex et Societatis, v3n8, hal. 91

${ }^{17}$ Gatot P. Sumartono, Op.cit, hal. 39

${ }^{18}$ Rochmani, Op.cit, hal. 23
} 
kewajiban dan komitmen pada terjaminnya pemenuhan HAM atas lingkungan hidup yang bersih dan sehat.

Salah satu bentuk tanggung jawab negara dalam perlindungan HAM dan lingkungan hidup adalah dalam pembentukan peraturan, baik yang termuat dalam Konstitusi maupun peraturan perundang-undangan lain. Hukum HAM yang di dalamnya terdapat atau terkandung norma-norma perlindungan hak asasi manusia secara bersamaan juga harus memuat perlindungan lingkungan untuk kepentingan bersama. Pengaturan HAM dan lingkungan hidup dalam konstitusi merupakan suatu perkembangan di era global yang mengatur perlindungan lingkungan hidup sebagai bagian dari HAM, mengingat hak atas lingkungan hidup yang bersih dan sehat merupakan hak yang fundamental bagi kehidupan manusia. Terkait dengan hal tersebut, diperlukan instrumen hukum lingkungan, di mana di dalamnya fungsi hukum tidak saja sebagai sarana perlindungan lingkungan hidup, pengendalian dan kepastian bagi masyarakat, melainkan juga sebagai sarana pembangunan.

\section{Perlindungan Lingkungan Hidup Dalam Hukum Nasional Indonesia}

Dalam Pasal 28 H Undang-Undang Dasar Negara Republik Indonesia Tahun 1945, menyatakan bahwa "setiap orang berhak hidup sejahtera lahir batih, bertempat tinggal, dan mendapatkan lingkungan hidup yang baik serta berhak memperoleh pelayanan kesehatan". Berdasarkan pengaturan tersebut, terlihat bahwa terdapat jaminan secara konstitusional mengenai hak warga negara untuk memperoleh lingkungan hidup yang baik dan sehat, di mana hal tersebut memiliki dua pengertian mendasar. Pertama, warga negara berhak untuk memanfaatkan dan mengelola sumber daya alam yang tersedia. Kedua, hak warga negara tersebut juga diimbangi dengan kewajiban untuk menjaga dan melestarikan lingkungan hidup agar dapat dinikmati juga oleh warga negara yang lain. Dalam hal ini, sebagaimana pembatasan dalam konsep HAM, di mana hak atas lingkungan hidup dibatasi oleh hak atas lingkungan hidup yang juga dimiliki oleh orang lain.

Selaras dengan perkembangan situsari internasional dan nasional terkait dengan semakin tajamnya isu perlindungan lingkungan hidup, pengaturan mengenai lingkungan hidup di Indonesia beberapa kali perubahan. Terakhir, Indonesia membentuk Undang-Undang Nomor 32 Tahun 2009 tentang Pengelolaan Lingkungan Hidup (UUPLH). Terkait dengan instrumen Hukum Lingkungan, Munadjat Danusaputro membedkan antara Hukum Lingkungan Modern yang berorientasi kepada lingkungan, dan Hukum Lingkungan Klasik yang berorientasi pada penggunan lingkungan. Hukum Lingkungan modern menetapkan ketentuanketentuan dan norma-norma guna mengatur tindak perbuatan manusia dengan tujuan untuk melindungi kelestariannya agar secara terus-menerus digunakan oleh 
generasi-generasi mendatang. ${ }^{19}$ N.H.T. Siahaan menyatakan beberapa hal yang perlu menjadi perhatian dalam instrumen Hukum Lingkungan adalah :

a. Hukum Lingkungan menjadi dasar dan pedoman dari segala pengelolaan lingkungan, di mana keseluruhan aspek yang diatur oleh hukum lingkungan adalah untuk keberlanjutan lingkungan bagi kesejahteraan manusia.

b. Kekuasaan pengelolaan berada di tangan negara.

c. Mengatur interaksi lingkungan dan interaksi manusia dengan manusia.

d. Keserasian sebagai asas pengelolaan lingkungan.

e. Berasaskan keberlanjutan. ${ }^{20}$

Sebagai bentuk turunan atas konstitusi, dalam Pasal 65 UUPLH diatur lima hak atas lingkungan hidup, yaitu :

a. Setiap orang berhak atas lingkungan hidup yang baik dan sehat sebagai bagian dari hak asasi manusia.

b. Setiap orang berhak mendapatkan pendidikan lingkungan hidup, akses informasi, akses partisipasi, dan akses keadilan dalam memenuhi hak atas lingkungan hidup yang baik dan sehat.

c. Setiap orang berhak mengajukan usul dan/atau keberatan terhadap rencana usaha dan/atau kegiatan yang diperkirakan dapat menimbulkan dampak terhadap lingkungan hidup.

d. Setiap orang berhak untuk berperan dalam perlindungan dan pengelolaan lingkungan hidup sesuai dengan peraturan perundang-undangan.

e. Setiap orang berhak melakukan pengaduan akibat dugaan pencemaran dan/atau perusakan lingkungan hidup.

Sebagaimana telah diungkapkan bahwa hak atas lingkungan hidup harus diimbamgi dengan adanya kewajiban terhadap lingkungan hidup itu sendiri. Dalam Pasal 67 UUPLH mengatur bahwa setiap orang berkewajiban memelihara kelestarian fungsi lingkungan hidup serta mengendalikan pencemaran dan/atau kerusakan lingkungan hidup. Ketentuan Pasal 67 memuat dua kewajiban bagi masyarakat dalam pengelolaan lingkungan hidup, yaitu kewajiban untuk memelihara kelestarian fungsi lingkungan hidup, dan kewajiban mengendalikan pencemaran dan/atau kerusakan lingkungan hidup. Dengan adanya hak atas lingkungan hidup yang baik dan sehat dengan kewajiban untuk memelihara fungsi lingkungan hidup serta kewajiban untuk mengendalikan lingkungan hidup, dapat dimaknai bahwa adanya keseimbangan dan keselarasan antara hak dan kewajiban masyarakat atas lingkungan hidup. Lingkungan hidup tidak akan menjadi baik dan sehat ketika masyarakat tidak memelihara kelestarian fungsi lingkungan hidup serta berupaya untuk mengendalikan pencemaran dan perusakan lingkungan hidup. ${ }^{21}$

\footnotetext{
${ }^{19}$ Munadjat Danusaputro, Op.cit, hal. 36

20 Ibid, hal. 53-59

21 Nopyandri. (2014). Hak Atas Lingkungan Hidup dan Kaitannya Dengan Peran Serta Dalam Pengelolaan Lingkungan Hidup Dalam Perspektif Otonomi Daerah. Jurnal Inovatif, v7n3, hal. 38
} 
Dalam konteks pengelolaan lingkungan hidup, berdasarkan UUPLH, penegakan hukum lingkungan dapat dilakukan melalui dua cara, yaitu secara preventif dan represif. Penegakan hukum lingkungan yang bersifat preventif adalah dilakukan melalui pengawasan, sedangkan penegakan hukum yang represif dilakukan melalui penerapan sanksi. Pengawasan dan penerapan sanksi tersebut bertujuan untuk mencapai ketaatan masyarakat terhadap norma hukum lingkungan. UUPLH mengupayakan adanya komitmen moral, politik dan sosial dari para pemangku kebijakan di bidang lingkungan hidup. Tidak hanya kepada para pemangku kebijakan, peran dan partisipasi masyarakat pun ditekankan sebagai bentuk pengawasan moral dari publik. Dengan keterlibatan seluruh pihak, tentu saja setiap upaya perlindungan terhadap lingkungan hidup dapat terlaksana, sekaligus menjadi sarana perlindungan HAM.

\section{Kesimpulan}

Perlindungan lingkungan hidup merupakan isu yang menjadi perhatian besar, mulai dari tingkat lokal, nasional, hingga internasional. Perhatian terhadap sektor lingkungan dimanifestasikan dalam berbagai aksi dan gerakan, baik oleh para pemangku kebijakan, masyarakat, dan kelompok sosial lainnya. Perlindungan lingkungan hidup menjadi bagian yang inheren dengan perlindungan HAM, mengingat adanya korelasi yang sangat erat antara lingkungan hidup dengan manusia. Berbagai instrumen hukum di tingkat internasional dan nasional dibentuk guna menjamin pemenuhan hak atas lingkungan sebagai bagian dari HAM, dimana hak atas lingkungan yang baik dan sehat hak yang fundamental dalam diri manusia dan dapat memperkuat konstruksi kehidupan manusia. Di tingkat nasional, sudah menjadi kewajiban bagi negara untuk memberikan jaminan perlindungan lingkungan hidup sebagai bentuk perlindungan HAM yang diakuinya dalam bentuk kebijakan hukum atau peraturan perundang-undangan.

\section{REFERENSI}

Abdurrahman Supardi Usman. (2018). Lingkungan Hidup Sebagai Subjek Hukum : Redefinisi Relasi Hak Asasi Manusia dan Hak Asasi Lingkungan Hidup Dalam Perspektif Negara Hukum, Jurnal Legality, v26n1

F.X. Adisusanto, Maria Ratnaningsih, Bernadeta Harini Tri Prasasti (ed), 2016, Laudato Si Terpujilah Engkau, Jakarta: Departemen Dokumentasi dan Penerangan Konferensi Waligereja Indonesia

Gatot P. Soemartono. (1996). Hukum Lingkungan Indonesia,Jakarta: Sinar Grafika

M. Ridha Saleh. (2006). Lingkungan Hidup : Untuk Penghidupan Bukan Untuk Pertumbuhan, Jakarta: WALHI 
Majda El-Muhtaj, (2008), Dimensi-Dimensi HAM Mengurai Hak Ekonomi, Sosial, dan Budaya, Jakarta: PT Raja Grafindo Persada

Morais Barakati. (2015). Perspektif Konsep Hukum Hak Asasi Manusia Dalam Mewujudkan

Pembangunan Lingkungan Hidup Yang Berkelanjutan, Jurnal Lex et Societatis, v3n8

Munadjat Danusaputra. (1985). Hukum Lingkungan, Buku I, Jakarta: Binacipta

Otto Soemarwotto. (1997). Ekologi Lingkungan dan Pembangunan, Jakarta: Djambatan

Nopyandri. (2014). Hak Atas Lingkungan Hidup dan Kaitannya Dengan Peran Serta Dalam Pengelolaan Lingkungan Hidup Dalam Perspektif Otonomi Daerah. Jurnal Inovatif, v7n3

Richard V. Waas, (2014), Perlindungan Hukum Terhadap Hak Atas Lingkungan Hidup Ditinjau Dari Perspektif Hukum Internasional dan Hukum Nasional Indonesia, Jurnal Sasi, v20n1

Rochmani, (2015), Perlindungan Hak Atas Lingkungan Hidup Yang Baik Dan Sehat di Era Globalisasi, Jurnal Masalah-Masalah Hukum, v44n1 